\title{
An audit on the use of antibiotics in watery/mucoid diarrhea at admission to hospital
}

\author{
K S H de Silva ${ }^{1}$, Sirimali Fernando ${ }^{2}$, S F N Gajamange ${ }^{3}$, S P Sumanasena ${ }^{4}$, I Suraweera ${ }^{5}$, D J M N R Jayamaha ${ }^{6}$
}

Sri Lanka Journal of Child Health, 2001; 30: 28-30

(Key words: watery/mucoid diarrhoea, antibiotics, oral rehydration therapy)

\begin{abstract}
Introduction Acute gastroenteritis causing watery diarrhoea is a common childhood problem managed in the majority of instances with oral rehydration therapy. But it is common for antibiotics to have been used in this condition prior to admission to hospital. This study was done to document the use of antibiotics in watery/mucoid diarrhoea.
\end{abstract}

Method The bystanders of 296 children $<12$ years admitted with watery/mucoid diarrhoea to the University Paediatric Unit at the Lady Ridgeway Hospital from November 1996 to July 1998 were interviewed regarding the treatment their children had received during the current illness. The patients' stools were cultured for Shigella, Salmonella and Escherichia coli species and tested for Rotavirus

Results All patients had received either home based remedies or antibiotics or both prior to admission. One hundred and ninety nine patients $(28.6 \%)$ had been given antibiotics and lime juice and 'Jeevani' had been offered to $190(64.2 \%)$ and $175(59.1 \%)$ children respectively. Of the 199 patients who had received an antibiotic, the drug was positively identified by name in $57(28.6 \%)$. The commonest drug used was furazolidone (in $26(45.6 \%)$ of them. In spite of antibiotics having been used, bacterial pathogens were isolated from $52(26 \%)$ samples including 4 Shigella isolates and rotavirus was detected from $30(15 \%)$ samples.

Conclusions In most instances antibiotics should be avoided in watery diarrhoea as the indiscriminate use of these can lead to emergence of drug resistance.

${ }^{1}$ Senior Lecturer in Paediatrics, University of Colombo, ${ }^{2}$ Head \& Senior Lecturer in Microbiology, ${ }^{3}$ Lecturer in Microbiology, University of Sri Jayawardenepura, ${ }^{4}$ Registrar, Colombo South Teaching Hospital, ${ }^{5}$ Medical Officer, ${ }^{6}$ Registrar in Surgery, National Hospital, Colombo.

\section{Introduction}

Acute gastroenteritis is common in children being an important cause of admission to hospital ${ }^{1}$. Antibiotics are generally not indicated in the management of this condition $1^{2}$. But as commonly observed in hospital practice, most children with watery diarrhoea have had antibiotics during the course of their illness prior to admission. This misuse of antibiotics poses problems in the subsequent management as the side effects of the commonly used drugs enhances the symptoms associated with diarrhoea such as vomiting and makes the possibility of culturing a bacterial pathogen remote. Therefore this study was undertaken to document the use of antibiotics in watery/mucoid diarrhoea and to identify factors which may have justified their use.

\section{Method}

Two hundred and ninety six children under 12 years of age admitted with watery or mucoid diarrhoea to the University Paediatric Unit at the Lady Ridgeway Hospital, Colombo from November 1996 to July 1998 were prospectively studied. An interviewer administered questionnaire was used to document the clinical details and home management/treatment of the patients prior to admission to hospital. It was decided that an antibiotic had been given if the bystander could identify the drug by name, the bottle or tablets were available for identification, if the drug was reconstituted prior to administration and by the description of the tablets or capsules.

The mothers were requested to collect a sample of stools unmixed with urine into a plain screw capped bottle. A swab was taken from the sample and transported in Carey Blair medium. When mucus was present the swab was made from the mucoid area. The stool samples were cultured for Shigella, Salmonella and Escherichia coli species in Salmonella-Shigela agar and MaConkey agar and tested for Rotavirus by the ELISA technique $\left(\right.$ Vellcozyme $\left.^{\mathrm{TM}}\right)$. 


\section{Results}

All patients had received either home remedies or antibiotics or both prior to admission and this is summarized in Table 1. Antibiotics had been given to 199 patients $(67.2 \%)$ and $175(59.1 \%)$ had been offered 'Jeevani'. Lime juice had been given to 190 patients $(64.2 \%)$ and was the commonest home based fluid used.

The antibiotic given was positively identified in 57 of the 199 patients $(28.6 \%)$ who had received an antibiotic (Table 2). Furazolidone was the commonest drug used in $26(45.6 \%)$ patients.

In an attempt to identify the possible reasons for antibiotics to have been given, the age and clinical features in the patients who had received antibiotics were compared with those who hadn't (Table 3). Being an infant was not significantly associated with the use of antibiotics and neither was the presence of fever, vomiting or abdominal pain. Presence of straining and tenesmus which are reported features of bacillary dysentery ${ }^{3}$ were also not the reasons for using antibiotics. The only statistically significant difference in the clinical features of the patients who had received antibiotics was the presence of mucus in the stools $(\mathrm{p}<0.05)$.

In spite of antibiotics having been used, bacterial pathogens were isolated from 52 samples and rotavirus was detected from 30 patients (Table 4). Of the 4 shigella isolates, 2 were from mucoid stools while 3 of the 16 entero toxigenic E. coli (ETEC) isolates were from patients with mucoid diarrhoea.

\section{Table 1 - $\quad$ Treatment received prior to hospital admission}

$\begin{array}{cc}\text { Type of treatment received } & \text { Number of patients* } \\ \text { Antibiotics } & 199(67.2) \\ \text { 'Jeevani' } & 175(59.1) \\ \text { Lime juice } & 190(64.2) \\ \text { Coffee } & 103(34.8) \\ \text { 'Suduru' } & 96(32.4) \\ \text { Other fluids }^{\dagger} & 97(32.8)\end{array}$

* Percentages are in parenthesis

${ }^{\dagger}$ Other fluids - cunjee, king coconut water, water, tea

Table 2 - Antibiotics used in watery/mucoid diarrhoea at admission to hospital

$\begin{array}{cc}\text { Antibiotic } & \text { Number of patients } \\ \text { Furazolidone } & 26 \\ \text { Nalidixic acid } & 12 \\ \text { Pivmecillinam } & 2 \\ \text { Amoxycillin } & 5 \\ \text { Cotrimoxazole } & 4 \\ \text { Metranidazole } & 5 \\ \text { Gentamicin } & 3\end{array}$

Table 3 - $\quad$ Clinical features in the patients with watery/mucoid diarrhoea

$\begin{array}{lccc}\text { Clinical features } & \begin{array}{c}\text { No. of patients } \\ \text { Antibiotics given } n=199\end{array} & \begin{array}{c}\text { No. of patients } \\ \text { Antibiotics not given } n=97\end{array} & \text { Difference between proportions } \\ \text { Age }<1 \text { yr } & 120 & 58 & \mathrm{p}>0.05 \\ \text { Fever } & 95 & 46 & \mathrm{p}>0.05 \\ \text { Vomiting } & 139 & 67 & \mathrm{p}>0.05 \\ \text { Abdominal pain } & 75 & 29 & \mathrm{p}>0.05 \\ \text { Straining and tenesmus } & 45 & 19 & \mathrm{p}>0.05 \\ \text { Presence of mucus } & 73 & 25 & \mathrm{p}<0.05\end{array}$




\author{
Organism \\ Shigella species \\ E. coli \\ ETEC \\ Salmonella \\ Pleisomonas \\ Rota virus \\ Total
}

\author{
Number \\ $4(2 \%)$ \\ 39 \\ $16(8 \%)$ \\ 7 \\ 1 \\ $30(15.1 \%)$ \\ 52
}

\section{Discussion}

Acute gastroenteritis resulting in watery diarrhoea is a very common occurrence in childhood. In most instances the only treatment necessary is the prevention of dehydration by the use of oral rehydration therapy (ORT) including 'Jeevani' ${ }^{1}$. The majority of watery diarrhoeas in childhood do not need to be treated with antibiotics ${ }^{2}$. But shigellosis which warrants treatment with antibiotics can present initially with watery diarrhoea ${ }^{3,4}$ and may be difficult to differentiate clinically from viral infections. Of the other bacterial pathogens causing watery diarrhoea ETEC may need antibiotics under certain circumstances such as in traveller's diarrhoea ${ }^{5}$. Presence of mucus in the stools is an important symptom as it has been reported that green mucoid stools are significantly associated with infection with Shigella species ${ }^{6}$. Therefore easy access to culture facilities and/or the availability of rapid diagnostic tests to detect bacterial antigens in stools would be very useful in the management of this common childhood problem.

In spite of having had antibiotics, Shigella species and ETEC were isolated from 20 samples (10.1\%) which suggests that the antibiotics used were either inappropriate and/or the duration of treatment and doses were inadequate. Persistence of Rotavirus has been documented after the use of antibiotics in watery diarrhoea. This was seen in our study as Rotavirus was isolated from 30 out of the 199 samples (15.1\%) taken from the children who had received antibiotics although the duration of persistence was not recorded.

\section{Conclusions}

This audit illustrates the indiscriminate use of antibiotics which can lead to an emergence of drug resistance. Hence antibiotics should be avoided in watery diarrhoea, unless a bacterial pathogen which warrants treatment has been isolated.

\section{Acknowledgements}

This study was possible due to grants from the Universities of Colombo and Sri Jayawardenapura.

\section{References}

1. Sonnadara D A. Management of watery diarrhoea. Sri Lanka Journal of Child Health 2000; 29(3): 63-4.

2. Wong H B. Infections. In: Campbell A G M, McIntosh Neil, editors. Forfar and Arneil's Textbook of Paediatrics. 4th ed. UK: Churchill Livingstone, 1992; 1350-3.

3. Coulter J B S. Infections. In: Campbell AGM, McIntosh Neil, editors. Forfar and Arneil's Textbook of Paediatrics. 4th ed. UK: Churchill Livingstone, 1992; 1382-4.

4. Korzeniowski O M, Barada F A, Rouse J D, Guerrant R L. Value of examination for fecal leukocytes in the early diagnosis of shigellosis. American Journal of Tropical Medicine and Hygiene 1979; 28(6): 1031-5.

5. Turner D, Porat N, Cohen D, Yavzori $\mathrm{M}$ et al. Antibiotic resistance pattern of enterotoxigenic Escherichia coli isolated from infants and young adults in Israel. European Journal of Clinical Microbiology and Infectious Diseases 1998; 17(9): 666-9.

6. de Silva K S H, Fernando S, Gajamange S F N, Sumanasena S P et al. Value of stool microscopy in predicting a bacterial aetiology in watery or mucoid diarrhoea. Proceedings of The Sri Lanka College of Paediatricians Annual Scientific Congress 1999; 1(3): 44. 
